\title{
Breaking Boundaries: Current Research Trends in English Linguistics and Philology
}

\section{Merja Kytö, Jeremy J. Smith \& Irma Taavitsainen}

To cite this article: Merja Kytö, Jeremy J. Smith \& Irma Taavitsainen (2017) Breaking Boundaries: Current Research Trends in English Linguistics and Philology, Studia Neophilologica, 89:sup1, 1-4, DOI: $10.1080 / 00393274.2017 .1379886$

To link to this article: https://doi.org/10.1080/00393274.2017.1379886

册Published online: 11 Oct 2017.

Submit your article to this journal

Џlll Article views: 102

Q View related articles $\sqsubset$

View Crossmark data \lceil 


\title{
Breaking Boundaries: Current Research Trends in English Linguistics and Philology
}

\author{
Merja Kytö, Jeremy J. Smith and Irma Taavitsainen
}

Research in English language and literature (ELL), at the beginning of the $21^{\text {st }}$ century, covers a very broad span. The discipline has traditionally included linguistic studies of English and related varieties, and branches of English literary studies from Old English and early Renaissance literature to modernism and up to the present, but such an outline obscures an astonishingly wide range. And such breadth has now achieved official sanction, in the UK government's recent public assessment of its universities' research quality, the Research Excellence Framework of 2014, where the list of topics presented for consideration was outlined as follows:

all aspects of language studies, including all areas of linguistics and of applied linguistics, with primary reference to any variety of English or Scots; the history of English or Scots; Old Norse/Icelandic (language, literature and linguistic studies); English literature from the early Middle Ages to the present day; North American literature; comparative literature; world literatures in English; colonial and postcolonial literatures and languages; women's writing; creative writing; life writing; children's literature; critical and cultural theory; cultural history; gender and sexuality studies; editorial scholarship, bibliography, textual criticism and theory, and history of the book; Irish literature in English; Scottish literature in English and Scots; Welsh literature in English; and applied, practice based, and pedagogical research in English ('Panel criteria and working methods', REF 01.2012: 80, para 7).

The field of ELL has thus come to include a vast variety of topics. Clearly a 'discipline' that can contain such extremes is capacious indeed - so capacious that it may arguably be rather hard to describe it as a 'discipline' at all. More positively, it may be argued that this variety indicates a healthy willingness to interrogate the basis of the subject, in line with modern trends to interdisciplinarity.

With interdisciplinarity comes teamwork, and it is perhaps above all this teamwork that the papers included in the present volume celebrate: they all draw upon larger projects that require a range of skills and insights from interdisciplinary perspectives. Traditionally, research in the humanities is supposed to be pursued by 'lone scholars', working in libraries on their own and developing their own special insights from their own particular viewpoints. This picture has never really been true, even in arts disciplines; scholars have always interacted with their peers, but in the new interdisciplinary world it has become even harder for individuals to work on their own. The paper by Fitzmaurice et al. is perhaps the most obvious in this regard, in that it is multiauthored, but all the remaining single-authored articles (e.g. Tyrkkö) acknowledge freely their use of other resources, frequently originally created for other purposes, 
and refer to larger projects being developed by networks of researchers. Enlightenment scholars such as a Goethe or a Voltaire may have been inspired individuals, able to be expert in all relevant disciplines, but such polymathy is in modern conditions extraordinarily hard to sustain; scholars need to bring their own varieties of expertise to the table, engaging openly with others with very different disciplinary formations.

This breadth of interest and teamwork was well-reflected in the conference from which the papers in this special issue of Studia Neophilologica ultimately derive: the 2016 London conference of the International Association of University Professors of English (IAUPE). IAUPE was founded just after the Second World War with the aim of bringing together senior scholars in the field, able (in principle at least) to take a broad view of the discipline's direction, and the triennial conference has traditionally been a place to take stock. Although the papers that follow are, in comparative terms, more focused than the full range of offerings at IAUPE 2016, ${ }^{1}$ they nevertheless reflect something of the capaciousness of issues that preoccupied the wider conference. All the papers collected here were presented originally as part of the History of English strand and display a wide yet coherent array of studies from that section; ${ }^{2}$ they have since all gone through considerable revision and augmentation, and in some cases complete reworking.

Over the past few decades the study of the history of English language and literature has gone through a transformation regarding the materials and methodologies applied, most notably through technological advances. The compilation of computerized corpora and large-scale databases, and the development of sophisticated search techniques, have enabled researchers to explore further dimensions of study and drill deeper in the empirical foundations of the use and evolution of English. The first-generation corpora (e.g. the Brown family corpora, the Helsinki Corpus of English Texts) led to secondgeneration specialized corpora of early English correspondence, early medical writing, dialogue texts, newspapers and other genres. Yet a further step has been the advent of third-generation corpora of hundreds of millions of words, among them the linguistically annotated Corpus of Historical American English (COHA), and even the biggest resource of all, the World Wide Web (for details, see Taavitsainen et al. 2015). The transplanted varieties of English world-wide have also already received corpus compilers' and researchers' attention regarding both synchronic and diachronic studies. On the whole, the use of electronic evidence has been best felt in English linguistics and philology so far, but the powerful appeal of the digital humanities is also making literary scholars acknowledge the potential of the approach to their work.

In addition to individual texts, large or indeed massive electronic corpora are discussed in the contributions submitted to the present issue. The materials studied range from the official Hansard record of the British parliament (Archer) and promotional playbills from nineteenth-century Scotland (Dossena) to the fifteenth-century Paston letters (Nakayasu), from analyses of large-scale corpora such as the COHA corpus (Jucker) and the machine-readable version of Early English Books Online undertaken by the Text Creation Partnership (EEBO-TCP) (Fitzmaurice et al.) to the paratextual features of early and late modern medical texts (Tyrkkö) and the close analysis of punctuation in copies of a late Middle English version of the life of Christ (Smith).

Now, although these topics at first sight all seem very disparate, on closer inspection some common themes are evident. First, there is throughout a concern with sociocultural contexts. Texts are not discussed as raw data with a view to constructing broad- 
brush 'rules' but, rather, as human products situated in particular points in time and space. Many of the papers (e.g. Archer, Fitzmaurice et al., Jucker, Nakayasu) are informed by digital tools of considerable sophistication, but all address the problem of textual individuality head-on. Archer, for instance, is careful to interpret the deployment of 'unparliamentary language' in Hansard in the light not only of the peculiar customs of the British parliament but also in close relationship to the contextconditioned striving for party advantage that these rituals are designed to manage. Fitzmaurice and her team indeed have the ambitious aim of correlating diachronic linguistic developments with broad intellectual and social trends. However, their aim is to identify 'keywords' (to use a term first made fashionable by Raymond Williams back in 1983) that can be studied in particular texts produced at particular points of time. John Speed's history of Britain (1611) is chosen as an example; the authors show that Speed's lexical choices are conditioned by an ideological driver, an attempt to reflect in cultural terms the new 'united kingdom' that followed from the 1603 Union of Crowns between Scotland, England and Wales. In their analyses, Fitzmaurice et al. make use of the Historical Thesaurus and its spin-off projects, and so does also Archer. Nakayasu's discussion is similarly historically situated; it shows a clear correlation between the use of distal and proximal spatio-temporal discourse markers (e.g. those/these and their equivalents) and female and male letter-writers, to be most plausibly explained as to do with gendered power-relationships current in fifteenth-century England. And Jucker makes the issue explicit. At the end of his paper on greetings and farewells in American English he states quite clearly as follows:

Salutation sequences (and presumably others) need to be studied in their specific cultural contexts, but search hits retrieved from corpora provide only a very limited amount of context, which for the pragmaticist is often insufficient to determine the relevant dimensions of the relationship between the speakers, their shared common ground and the larger conversational context in which the extract appears.

Jucker's statement is important because it catches very precisely the 'balancing-act' that many of the papers confront, between the study of large data on the one hand and engagement with the particular characteristics of individual texts on the other. As he and Irma Taavitsainen have shown in their English Historical Pragmatics (2013), the trick is to bring 'big data' and individual textual discussion into articulation. A problem in the historical pragmatics approach is, of course, that correlating complex socio-cultural contexts with textual form makes some rather special demands on those undertaking the research in question. In our preparatory call for papers in our section at IAUPE 2016 we stated as follows:

In recent years English historical linguistics has reasserted the connection between linguistic theorising and the close study of texts, and outlined the recent past in a few words, how the discipline had been transformed through electronic corpora, massive repurposing/ reworking of nineteenth-century dictionary-enterprises into modern electronic tools and new ways of mapping the varieties of English through time and space. We can search, categorise, and analyse statistically the 'big data' that underpin our discipline in ways that simply could not have been imagined a generation or so ago. The insights that derive from the quantitative analysis of data have been productively complemented by qualitative research, taking the socio-cultural conventions and contexts into account. We advocated contextualisation of language and taking into account the special qualities of the texts from which the data are drawn. Questions of genre, register, and reception are all increasingly 
crucial, demanding interdisciplinary engagement with research into the private and public spheres, social networks, material culture including book history, and the history of literacy.

All the papers presented below engage with such interdisciplinary issues. Thus, for instance, both Smith's and Tyrkkö's studies range beyond the realm of what is traditionally considered 'linguistic' to engage with features such as images, punctuation, script and typeface. Such features - referred to in passing as well by Dossena - are shown to be, just as much as lexical or grammatical choices, vectors of meaning for those who encountered these texts when they were created. Excitingly Dossena and Tyrkkö use multimodal approaches, drawing upon images digitised for other purposes and developing new tools for their analysis. In these papers the realms of palaeography, codicology and bibliography are being brought into articulation with more 'traditional' philology as conceived of since the nineteenth century.

The intellectual generosity required for such an enterprise is well illustrated by the papers that follow, and indeed one of the pleasures of the sessions at IAUPE was the ways in which those present demonstrated their openness to new perspectives. What came across very strongly was that the paradigm known as 'historical pragmatics', with which these papers may all in their various ways be considered to be concerned, is not just capacious in the manner of the wider discipline of ELL: it is also hospitable. Our aim in the sessions at IAUPE was in some sense a simple one: to invite prominent researchers who had recently launched or were planning projects on the history of English to present their papers and align them with what they conceived to be 'the state of the art'. It is clear from these papers that we are engaged on a reframing of the whole philological enterprise in a new interdisciplinary direction, allowing for new and better explanations for the phenomena to be observed (see also Roberts and Darby (forthcoming [2017]).

\section{Notes}

1. The topics covered in the conference ranged from a study of the remastered recordings of the Beatles to ambiguity in multilingual medieval glosses (see http://www.ies.sas.ac.uk/sites/ default/files/files/events/conferences/IAUPE/IAUPE\%20Programme.pdf, last accessed on 14 April 2017).

2. Two contributions, one on historical linguistics by Minoji Akimoto and the other on multimodal discourse by Isabel Ermida will come out in the general volume edited by Roberts and Darby (forthcoming [2017]).

\section{References}

Jucker, Andreas H. \& Irma Taavitsainen. 2013. English historical pragmatics. Edinburgh: Edinburgh University Press.

Roberts, Jane \& Trudi L. Darby (eds.). Forthcoming [2017]. English without boundaries: Reading English from China to Canada. Newcastle: Cambridge Scholars.

Speed, John. 1611. History of Great Britaine under the conquests of Romans, Saxons, Danes, and Normans (2 vols.). London.

Taavitsainen, Irma, Merja Kytö, Claudia Claridge \& Jeremy Smith. 2015. English in the digital age: General introduction. In Irma Taavitsainen, Merja Kytö, Claudia Claridge \& Jeremy Smith (eds.), Developments in English: Expanding electronic evidence, 1-8. Cambridge: Cambridge University Press.

Williams, Raymond. 1983. Writing in society. London and New York: Verso. 